\title{
HAK WARIS ANAK DALAM PERKAWINAN CAMPURAN
}

\author{
Setiawan Wicaksono
}

Fakultas Hukum Universitas Brawijaya

Jl. M.T. Haryono No.169, Ketawanggede, Kota Malang, Jawa Timur 65145

Telepon: +62341553898; Fax: +62341566505

E-mail: setiawanwicaksono@ub.ac.id

\begin{abstract}
Goals of this article which based on research are to find out inheritage rigthts of childrens born in an inter-religion (between non-muslim) after the judicial review about inter-religion marriage was decline by Indonesia Constitutional Court. Research method used in this article is normative legal studies. Approaches use in this research are conceptual approach and analytical approache. The results are inter-religion (between non-muslim) still possible to do because Counstitutional Court didn't set up new definition about marriage in Indonesia. Legality of marriage still in according to religion law on its own member. Children born in an relationship (outside marriage) and in an marriage still have inheritge rights.
\end{abstract}

Keywords: Marriage, Legality, Inheritage Rights

\begin{abstract}
ABSTRAK
Tujuan tulisan yang berdasarkan hasil penelitian ini bertujuan untuk mengetahui apakah perkawinan campuran (beda agama) dapat dilakukan di Indonesia pasca putusan Mahkamah Konstitusi yang menolak permohonan uji materiil Pasal 2 (1) Undang-undang No 1/1974. Selain itu, apakah perkawinan yang dilakukan pasangan berbeda agama akan memiliki dampak terhadap hak mewaris anak. Metode penelitian yang digunakan adalah yuridis normatif dengan pendekatan konseptual dan pendekatan analitis. Hasil yang diperoleh adalah perkawinan beda agama masih mungkin untuk dilakukan karena putusan Mahkamah Konstitusi tidak menegaskan larangan perkawinan beda agama. Anak hasil hubungan antara orang yang melakukan perkawinan beda agama tetap memiliki hak waris sebagai anak.
\end{abstract}

Kata kunci: Perkawinan, Keabsahan, Hak Waris

\section{LATAR BELAKANG}

Pasal 28B UUD Negara Republik Indonesia 1945 menyebutkan setiap orang berhak untuk membentuk keluarga dan melanjutkan keturunan melalui perkawinan yang sah. Pasal ini memberikan hak kepada setiap warga Negara Indonesia untuk melangsungkan perkawinan dengan siapapun. Perkawinan dalam kenyataannya dapat terjadi dengan beberapa kemungkinan, yaitu antara sesama Warga Negara Indonesia, antara Warga Negara Indonesia dengan Warga Negara Asing, bahkan perkawinan beda agama. Perkawinan seperti tersebut, sudah terjadi sejak sebelum kemerdekaan Indonesia (pada masa penjajahan Belanda) dan hingga kini setelah Indonesia merdeka.

Pada perkawinan antara sesama Warga Negara Indonesia yang beragama sama tidak menimbulkan permasalahan baik dari segi 
administrasi maupun hukumnya. Lain halnya dengan perkawinan beda agama. Perbedaan agama dalam melangsungkan perkawinan ternyata membawa permasalahan sendiri yang pada akhirnya Pemerintah Hindia Belanda melalui Staatsblaad 1898 No. 158 tentang Ordonansi Perkawinan mengatur tentang perkawinan beda agama yang disamakan dengan perkawinan campuran.

Pasal 1 Ordonansi Perkawinan menyebutkan bahwa "Yang dinamakan perkawinan campuran adalah ialah perkawinan antara orang - orang di Indonesia yang tunduk pada hukum yang berlainan”. Pasal 7 Ordonansi Perkawinan menyatakan "Perbedaan agama, suku, bangsa atau keturunan, sama sekali bukanlah menjadi halangan untuk perkawinan”. Dengan demikian berdasarkan Staatsblaad 1898 No. 158 perkawinan beda agama di Indonesia adalah sah dan dapat dilakukan.

Seiring dengan perkembangan zaman dan pasca kemerdekaan Indonesia, melalui pembentukan peraturan tentang perkawinan dengan Undang-undang Nomor 1 Tahun 1974, pengaturan perkawinan di Indonesia memiliki cerita yang berbeda. Undangundang Nomor 1 Tahun 1974 tentang perkawinan diundangkan pada tanggal 2 Januari 1974 dan berlaku secara efektif pada 1 Oktober 1975.

Pasal 1 Undang undang No. 1 Tahun 1974, memberikan pengertian perkawinan ialah ikatan lahir batin antara seorang pria dan seorang wanita sebagai suami isteri dengan tujuan membentuk keluarga (rumah tangga) yang bahagia dan kekal berdasarkan Ketuhanan Yang Maha Esa. Berdasarkan Pasal 1 tersebut dapat dirumuskan unsur perkawinan, yaitu:

1. Perkawinan merupakan ikatan lahir batin antara seorang pria dan seorang wanita.

2. Perkawinan bertujuan untuk membentuk keluarga (rumah tangga) yang kekal dan bahagia.

3. Perkawinan berdasarkan Ketuhanan Yang Maha Esa.

Keabsahan perkawinan diatur dalam Pasal 2 Undang undang No. 1 Tahun 1974 yang berbunyi:

(1) Perkawinan adalah sah apabila dilakukan menurut hukum masing-masing agamanya dan kepercayaannya itu

(2) Tiap-tiap perkawinan dicatat menurut peraturan perundang-undangan yang berlaku.

Pasal ini bermakna bahwa perkawinan adalah sah jika dilaksanakan menurut agama masing-masing dicatatkan menurut undangundang yang berlaku dalam hal ini berdasarkan Peraturan Pemerintah Nomor 9 Tahun 1975 tentang Pelaksanaan Undangundang Nomor 1 Tahun 1974 tentang Perkawinan. Adanya UU No. 1/1974 dan PP No. 9/1975. Lahirnya Undang-undang Perkawinan ini menghapus Staatsblaad 1898 No. 158 yang sebelumnya berlaku di Indonesia. 
Walaupun sudah terbentuk Undangundang yang baru bukan berarti Pasal 2 UU No. 1/1974 tidak menimbulkan permasalahan dalam prakteknya. Beragam perkawinan beda agama terjadi di Indonesia karena terjadi perbedaan penafsiran terkait keabsahan perkawinan. Pelaku perkawinan beda agama dan bahkan ahli hukum menafsirkan berbedabeda Pasal 2 ayat (1) UU No 1/1974. Penjelasan Pasal 2 (1) UU No 1/1974 hanya memberikan penjelasan sebagai berikut:

\section{"Dengan perumusan pada Pasal 2 ayat (1) ini, tidak ada perkawinan di luar hukum masing masing agamanya dan kepercayaannya itu, sesuai dengan Undang- Undang Dasar 1945. Yang dimaksud dengan hukum masing masing agamanya dan kepercayaannya itu termasuk ketentuan perundang undangan yang berlaku bagi golongan agamanya dan kepercayaannya itu sepanjang tidak bertentangan atau tidak ditentukan lain dalam Undang-undang ini."}

Akibat penjelasan yang tidak jelas, maka timbul berbagai macam penafsiran, antara yang beranggapan bahwa perkawinan beda agama tetap dapat dilangsungkan selama memenuhi ketentuan agama dari masingmasing individu dan dicatatkan dengan sebagian yang beranggapan bahwa perkawinan beda agama tidak dapat dilakukan.

Pasal 57 UU No 1/1974 hanya mengatur tentang perkawinan yang dilakukan antara dua orang yang tunduk pada dua hukum yang berlainan, yang disebut sebagai perkawinan campuran. Ketentuan mengenai perkawinan beda agama tidak diatur secara detil dalam Undang-undang ini.

Hemat penulis, kata "hukum" sendiri bisa saja diartikan sebagai hukum agama atau sistem hukum yang berlaku kepada individu. Jika "hukum" diartikan sebagai hukum agama, maka perkawinan beda agama bisa saja dilakukan dan sah di Indonesia. Namun, kenyataannya, tidak pernah ada kejelasan apa yang dimaksud hukum dalam Pasal ini.

Sebagai akibat dari pernah berlakunya Staatsblaad 1898 No. 158 dan ketidakjelasan yang ditimbulkan UU No 1/1974, perkawinan beda agama di Indonesia tetap ada setelah berlakunya UU No 1/1974. Berbagai cara dilakukan pasangan beda agama yang akan melangsungkan perkawinan beda agama.

Mulai dari melangsungkan pernikahan di luar negeri yang kemudian kembali ke Indonesia untuk dicatatkan di Kantor Catatan Sipil sehingga perkawinan mereka menjadi sah secara administratif hingga beberapa pasangan mengajukan upaya hukum ke badan peradilan di Indonesia.

Pasangan beda agama yang akan melangsungkan beda agama dianggap mengalami diskriminasi karena Pasal 2 ayat (1) UU No 1/1974 tersebut seringkali juga digunakan untuk menghambat pasangan yang 
akan melangsungkan perkawinan beda agama. $^{1}$

Menurut Guru Besar Hukum Perdata Universitas Indonesia Prof. Wahyono Darmabrata ada empat cara popular yang ditempuh pasangan beda agama agar pernikahannya dapat dilangsungkan, yaitu (1) meminta penetapan pengadilan, perkawinan dilakukan menurut masingmasing agama, (3) penundukan sementara pada salah satu agama, dan (4) menikah di luar negeri. ${ }^{2}$

Putusan Mahkamah Agung Nomor 156 /Pdt.P/2010/PN.Ska. dan Putusan Mahkamah Agung Nomer: 112/Pdt.P/2008/PN.Ska adalah contoh putusan Mahkamah Agung yang memberikan izin untuk dilangsungkan pernikahan beda agama di Indonesia dan dicatatkan di Catatan Sipil sehingga perkawinan beda agama yang telah dilangsungkan sah secara hukum. Yuni Shara dan Henry Siahaan salah satu contoh pasangan beda agama yang berhasil dicatatkan di Catatan Sipil setelah melangsungkan perkawinan di Perth, Australia. $^{3}$

Namun, sejak adanya putusan Mahkamah Konstitusi Nomor 68/PUU-XII/2014,

muncul anggapan bahwa perkawinan beda agama di Indonesia dilarang. Mahkamah Konstitusi menganggap UU Perkawinan ini telah dapat mewujudkan prinsip-prinsip yang terkandung dalam Pancasila dan UUD 1945 serta dapat menampung segala kenyataan yang hidup dalam masyarakat. Terlebih, Pasal 28J UUD 1945 menyebutkan dalam menjalankan hak dan kebebasannya setiap warga negara wajib tunduk terhadap pembatasan yang ditetapkan UndangUndang yang salah satunya dengan pertimbangan nilai-nilai agama. ${ }^{4}$

Maria Farida Indrati memiliki alasan berbeda dalam hal ini. Menurutnya, UU No 1/1974 memberikan solusi bagi mereka yang terpaksa melangsungkan perkawinan beda agama dan kepercayaan karena perkawinan merupakan peristiwa hukum yang menimbulkan hak dan kewajiban bagi mereka yang sudah menikah. ${ }^{5}$

Menurut Ahmad Nuryani, perkawinan merupakan sebuah lembaga yang memberikan legimitasi seorang pria dan wanita untuk bisa hidup dan berkumpul bersama dalam sebuah keluarga. Ketenangan atau ketenteraman sebuah 68/PUU-XII/2014, keluarga ditentukan salah satunya adalah

\footnotetext{
1 http://nasional.kompas.com/read/2014/09/06/09352001/UU.Perkawinan.Mendiskriminasi.Pasangan.Beda. Agama, diakses pada tanggal 17 September 2017 pukul 17.00.

2 http://www.hukumonline.com/klinik/detail/cl290/gimana-caranya, diakses pada tanggal 17 September 2017 pukul 17.00

3 http://www.hukumonline.com/berita/baca/hol6268/uu-perkawinan-tidak-melarang-perkawinan-bedaagama, diakses pada tanggal 17 September 2017 pukul 17.00 WIB.

4 Putusan Mahkamah Konstitusi Nomor 68/PUU-XII/2014.

5 Putusan Mahkamah Konstitusi Nomor 68/PUU-XII/2014.
} 
bahwa pernikahan itu harus sesuai dengan tuntutan syariat Islam (bagi orang Islam). Selain itu, ada aturan lain yang mengatur bahwa pernikahan itu harus tercatat di Kantor Urusan Agama atau Kantor Catatan Sipil Pencacatan perkawinan pada prinsipnya merupakan hak dan kewajiban dalam keluarga. Selain itu merupakan upaya perlindungan terhadap isteri maupun anak dalam memperoleh hak-hak keluarga seperti hak waris dan lain-lain. ${ }^{6}$

Sebagaimana telah dijelaskan Ahmad Nuryani, bahwa perkwainan merupakan upaya perlindungan terhadap segala sesuatu yang terjadi di dalam keluarga, salah satunya adalah warisan terhadap anak. Jika perkawinan dilakukan sebelum keluarnya putusan Mahkamah Konstitusi tersebut seharusnya anak dapat mewarisi harta pewaris, namun hal ini perlu dilihat secara kasuistis, artinya melihat dari agama yang ada dalam perkawinan beda agama tersebut. Perkawinan beda agama dapat terjadi antara Islam dengan Non-Islam atau keduanya samasama Non-Islam

Perkawinan beda agama yang telah ada di Indonesia sebelum keluarnya putusan tersebut tetap sah selama telah dicatatkan di Catatan Sipil dan seharusnya berhak untuk mendapatkan warisan dari pewaris. Machicha Mochtar adalah salah satu ibu yang memperjuangkan supaya anak hasil pernikahan siri mendapatkan hubungan perdata dengan ayahnya melalui uji materiil dan dimenangkan berdasarkan Putusan Mahkamah Konstitusi Nomor 46/PUUVII/2010. Hal ini membuktikan bahwa kepastian hukum dan perlindungan waris merupakan hal yang penting dalam sebuah keluarga.

Namun, berdasarkan keputusan hakim, anak hasil perkawinan beda agama yang sah (telah dicatatkan di Catatan Sipil dan sebelum putusan MK 68/PUU-XII/2014). Hingga kini, anak hasil perkawinan beda agama antara pasangan beragama Islam dengan NonIslam, tidak dapat mendapatkan warisan dari pewaris. Putusan Mahkamah Agung Nomor : 1578 /Pdt . G/2010 /PA.JT. dalam gugatan warisan antara ahli waris yang beragama Katolik dengan pewaris yang beragama Islam, diputuskan tidak berhak mendapatkan warisan sesuai dengan Kompilasi Hukum Islam bahwa pewaris muslim tidak boleh mewaris pada ahli waris non-muslim walaupun penggugat adalah anak kandung. Begitu juga dengan putusan Mahkamah Agung Nomor:4/Pdt.P/2013/PA.Bdg yang menyatakan bahwa ahli waris non-muslim tidak berhak mewaris dari pewaris muslim.

Hingga saat ini, juga telah banyak penelitian yang meneliti tentang hak mewaris

6 Ahmad Nuryani, Dasar Hukum Pencatatan Pernikahan di Indonesia, Bandung: Kantor Urusan Agama Kecamatan Gedebage, 2010. 
dari ahli waris dalam perkawinan beda agama antara Muslim dengan non-Muslim, dan semuanya menyatakan bahwa ahli waris NonMuslim tidak berhak mewaris dari pewaris Muslim berdasarkan Kompilasi Hukum Islam. Namun, perkawinan beda agama tidak selalu antara Muslim dengan Non-Muslim, namun bisa juga terjadi antara sesama NonMuslim. Perkawinan antara Kristen dan Katolik contohnya, masih dimungkinkan dengan beberapa syarat tertentu dari Gereja tempat dilangsungkannya perkawinan ${ }^{7}$, pemenuhan syarat tertentu perlu dilakukan sebelum dilangsungkan perkawinan beda agama $^{8}$.

Perkawinan yang dilakukan oleh sesama muslim diadakan dihadapan dan di Kantor Urusan Agama sebagai salah satu persyaratan keabsahannya. Kantor Urusan Agama hanya memiliki kewenangan untuk mensahkan perkawinan antara sesama muslim, sehingga bagi perkawinan beda agama antara sesama non-muslim pencatatan perkawinannya dilakukan di Kantor Catatan Sipil. Namun, hingga kini masih diperlukan kajian lebih mendalam apakah pencatatan yang dilakukan di catatan sipil merupakan syarat sahnya perkawinan bagi perkawinan campuran antara sesama non-muslim atau hanya syarat administrasi saja. Putusan MK No. 68/PUU-
XII/2014 tidak memberikan penjelasan terkait fungsi pencatatan dalam perkawinan campuran antara sesama non-muslim. Ketidakjelasan ini perlu dibahas supaya ditemukan suatu jawaban apakah perkawinan campuran antara sesama non-muslim sah atau tidak terutama setelah adanya putusan MK tersebut. Hal ini akan berpengaruh terhadap status anak dalam perkawinan campuran tersebut.

Perkawinan beda agama yang melibatkan Muslim sebagai salah satu pihaknya, menyebabkan Kompilasi Hukum Islam dapat berlaku di dalamnya, perkawinan beda agama antara sesama Non-Muslim tidak dapat diselesaikan menurut agama karena hukum agama tidak berlaku di Indonesia melainkan menggunakan hukum positif Indonesia.

Hingga saat ini, penulis belum menemukan penelitian dan analisis bagaimana kedudukan anak dan hak mewaris bagi anak hasil perkawinan beda agama antara sesama Non-Muslim, padahal perkawinan antara sesama Non-Muslim juga merupakan perkawinan beda agama sehingga perlu dikaji lebih lanjut bagaimana kedudukan dan hak mewaris anak tersebut. Undang-undang Nomor 1 Tahun 1974 tentang Perkawinan tidak mengatur hak mewaris dari pasangan perkawinan beda agama antara

7 http://www.hukumonline.com/berita/baca/lt5423d8219fb45/ini-pandangan-pendeta-hkbp-seputar-nikahbeda-agama, diakses pada tanggal 17 September 2017 pukul. 18.00 WIB

8 http://www.stmaria.info/read/berita-rohani/mixed-marriage-with-somebody-not-the-same-religionperkawinan-beda-agama-menurut-gereja-katolik\#.Wb81iYglHIU, diakses pada tanggal 17 September 2017 pukul 18.00 WIB. 
sesama Non-Muslim dan hukum agama masing-masing pasangan tidak mengatur mengenai hal tersebut.

\section{PEMBAHASAN}

\section{Perkawinan Campuran Pasca Putusan Mahkamah Konsititusi}

Perkawinan di Indonesia dan pencatatannya di Indonesia diatur dalam dua peraturan, yaitu Undang-undang Nomor 1 Tahun 1974 tentang Perkawinan dan Peraturan Pemerintah Nomor 9 Tahun 1975 tentang Pelaksanaan Undang-undang Nomor 1 Tahun 1974 tentang Perkawinan.

Sahnya perkawinan diatur dalam Pasal 2 ayat (1) Undang-undang Nomor 1 Tahun 1974 yang menyatakan: "Perkawinan adalah sah, apabila dilakukan menurut hukum masing-masing agamanya dan kepercayaannya itu."

Undang-undang Nomor 1 Tahun 1974 tidak memberikan penjelasan terkait apa yang dimaksud sah apabila dilakukan menurut hukum masing-masing agamanya dan kepercayaannya itu. Ketiadaan penjelasan untuk pasal ini menyebabkan terdapat multitafsir dalam kehidupan sehari-hari.

Multitafsir yang muncul adalah, yaitu yang pertama bahwa perkawinan campuran antara yang berbeda agama adalah sah sepanjang hukum agama masing-masing individu tentang sahnya perkawinan telah terpenuhi. Kedua, kalangan yang berpendapat bahwa perkawinan campuran tidak sah karena sahnya perkawinan baru terjadi saat pasangan tersebut memiliki agama yang sama.

Undang-undang Nomor 1 Tahun 1974 hanya menafsirkan perkawinan campuran hanya perkawinan yang melibatkan antara dua orang yang berbeda kewarganegaraan, bukan untuk perkawinan yang melibatkan dua agama yang berbeda, walaupun bisa saja terjadi dalam perkawinan yang melibatkan kewarganegaraan yang berbeda, perbedaan agama juga terjadi di dalamnya.

Perkawinan campuran antara yang melibatkan dua agama, dimana salah satu pasangannya beragama Islam, sudah pasti tidak sah karena dalam Islam memang sudah menyebutkan bahwa perkawinan tidak dapat dilakukan antara Islam dengan non-Islam. Walaupun Pasal 2 ayat (1) UU Nomor Tahun 1974 ditafsirkan dengan berbagai macam interpretasi tetap saja kesimpulannya perkawinan antara seseorang yang beragama Islam dengan non-Islam tidak dapat dilakukan.

Namun demikian, bagi agama lainnya, masih terdapat pengaturan yang berbeda. Kristen dan Katolik misalnya, beberapa gereja masih mengijinkan perkawinan campuran yang berbeda agama selama syaratsyarat tertentu dapat dipenuhi.

Sejak lama di Indonesia, perkawinan campuran juga telah diatur dalam Staatsblad 1898 Nomor 158 yang memperbolehkan perkawinan campuran, bahkan beberapa kali 
Mahkamah Agung memerintahkan Kantor Catatan Sipil untuk mencatatkan perkawinan campuran tersebut.

Pada tahun 2014, beberapa orang mengajukan uji materiil terhadap Pasal 2 ayat (1) UU Nomor 1 Tahun 1974 ke Mahkamah Konstitusi yang pada intinya adalah memohon untuk memaknai Pasal 2 ayat (1) UU Nomor 1 Tahun 1974 menjadi: "Perkawinan adalah sah, apabila dilakukan menurut hukum masing-masing agamanya dan kepercayannya itu, sepanjang penafsiran mengenai hukum agamanya dan kepercayaannya itu diserahkan kepada masing-masing calon mempelai"

Mahkamah Konstitusi memutuskan dalam putusan No. 68/PUU-XII/2014, permohonan pemohon ditolak seluruhnya. Pemaknaan “....sepanjang penafsiran mengenai hukum agamanya dan kepercayaannya itu diserahkan kepada masing-masing calon mempelai" yang dimohonkan ditolak dan dengan demikian bunyi Pasal 2 ayat (1) UU Nomor 1 Tahun 1974 tetap seperti semula.

Mahkamah Konstitusi dalam putusan tersebut juga tidak memberikan pengertian dan penafsiran yang pasti terhadap Pasal 2 ayat (1) tersebut, sehingga walaupun Mahkamah Konstitusi telah menolak permohonan pemohon, hingga saat ini tetap belum ada penafsiran yang baku terhadap Pasal 2 ayat (2) tersebut. Ketiadaan penafsiran ini, tetap dapat menimbulkan perbedaan penafsiran termasuk dalam hal sah atau tidaknya perkawinan campuran antara sesama non Muslim sehingga perlu dikaji lebih lanjut apakah perkawinan campuran antara sesama non Muslim tetap dapat dilakukan dan sah setelah keluarnya putusan tersebut.

Kondisi ini sangat berbeda sekali dengan penafsiran makna "dikuasai Negara" dalam Pasal 33 UUD 1945 dalam judicial review Undang-undang Nomor 22 Tahun 2001 tentang Minyak dan Gas Bumi (putusan Mahkamah Konstitusi Nomor 36/PUU$\mathrm{X} / 2012$ dan dalam judicial review Undangundang Nomor 7 Tahun 2004 tentang Sumber Daya Air (putusan Mahkamah Konstitusi Nomor 85/PUU-XI/2013). Kedua putusan Mahkamah Konstitusi tersebut memberikan batasan dan definisi yang jelas terhadap frasa “dikuasai Negara” dalam Pasal 33 UUD 1945. Oleh karena itu, siapapun tidak lagi dapat menafsirkan makna "dikuasai Negara" selain dari yang disebutkan Mahkamah Konstitusi.

Meneliti apakah perkawinan campuran dapat dilakukan dan sah pasca putusan Mahkamah Konstitusi tersebut, maka ada tiga hal yang perlu dikaji, yaitu:

\section{Sahnya Perkawinan di Indonesia}

Perkawinan campuran telah diatur sejak zaman dahulu melalui Stb. 1898 Nomor 158 tentang Perkawinan Campuran. Aturan ini menjadi payung hukum perkawinan campuran sebelum lahirnya Undang-undang Nomor 1 Tahun 1974. Ruang lingkup Stb. 1898 Nomor 158 dapat dibedakan menjadi 
dua, yaitu menurut aliran luas dan aliran sempit. Menurut aliran luas, ruang lingkup Stb. 1898 Nomor 158 mencakup perkawinan antar golongan, perkawinan antar agama, dan perkawinan antar tempat. Bagi aliran sempit, Stb. 1898 Nomor 158 hanya meliputi perkawinan antar golongan saja. Berdasarkan Stb. 1898 Nomor 158 ini, perkawinan campuran di Indonesia adalah sah.

Tahun 1974, lahir Undang-undang Nomor 1 Tahun 1974 tentang Perkawinan yang mengatur tentang sahnya perkawinan adalah apabila dilakukan menurut hukum masing-masing agama dan kepercayaannya itu. Pasal ini menimbulkan multitafsir dalam perkembangannya karena dapat terjadi penafsiran sebagai berikut: pertama, dengan tidak diaturnya perkawinan antar agama, dengan demikian perkawinan antar agama tidak dilarang sepanjang hukum agama tidak melarangnya. Kedua, perkawinan antar agama dilarang karena ada ajaran yang menyebutkan perkawinan antar agama tidak diperbolehkan.

Ketiadaan penjelasan yang pasti untuk Pasal 2 ayat (1) UU No. 1 Tahun 1974 menyebabkan adanya celah penafsiran dan interpretasi mengenai siapa yang berhak untuk melakukan penafsiran terhadap Pasal ini dan bagaimana menafsirkan hukum agama dan kepercayaan dalam bidang perkawinan dan bagaimana perkawinan dianggap sah.
Perkawinan dalam pelaksanannya, melibatkan para pihak yang akan menikah, pemuka agama, dan pegawai pencatat perkawinan. Ketiga pihak tersebut semuanya terikat pada Pasal 2 ayat (1) UU. No. 1 Tahun 1974 dalam melaksanakan perkawinan, sehingga dapat muncul setidak-tidaknya 3 macam penafsiran yang berbeda-beda.

Ketiadaan kejelasan penfasiran terhadap pasal tersebut dapat menyebabkan pemahaman dan pengertian yang berbedabeda sehingga perkawinan yang seharusnya dapat dijalankan menjadi terhambat atau bahkan batal karena kekhawatiran akan melanggar pasal tersebut.

Setidak-tidaknya, menurut penafsiran penulis, Pasal 2 ayat (1) UU No. 1 Tahun 1974 dapat memunculkan penafsiran sebagai berikut: pertama, perkawinan beda agama dan kepercayaan boleh dan sah untuk dilakukan, kedua perkawinan beda agama dan kepercayaan boleh dilakukan namun tidak sah, perkawinan beda agama dan kepercayaan tidak boleh dan tidak sah dilakukan.

Berdasarkan beberapa putusan Mahkamah Agung sebelum keluarnya putusan MK ini, memperbolehkan bahkan memerintahkan Kantor Catatan Sipil untuk mencatatkan perkawinan beda agama. Alasan diperbolehkannya perkawinan beda agama ini karena UU Nomor 1 Tahun 1974 tidak mengatur bahwa perkawinan beda agama dan 
kepercayaan merupakan suatu larangan perkawinan.

Walaupun demikian, hakim-hakim juga ada yang menyatakan bahwa perkawinan beda agama dan kepercayaan tidak dapat dilakukan (Penetapan Nomor 08/Pdt.P.2013/PN. Ung dan Penetapan Nomor 527/Pdt/P/2009/PN.Bgr) dengan alasan bahwa agama adalah unsur perkawinan yang tidak dapat dilepaskan dan terikat.

Pemerintah dalam penjelasannya terkait uji materiil Pasal 2 ayat (1) UU No. 1 Tahun 1974 juga menegaskan bahwa sah atau tidaknya sebuah perkawinan di Indonesia ditentukan oleh masing-masing agama yang diakui di Indonesia, bukan oleh Negara. Sepanjang agama-agama yang diakui di Indonesia menyatakan bahwa perkawinan adalah sah, maka Negara hanya mencatatkan saja perkawinan tersebut ke sistem administrasi Negara. Dengan demikian Pasal ini telah memenuhi dan melaksanakan Pasal 28B ayat (1) UUD 1945, yaitu untuk menjamin hak-hak konstitusional warga Negara dalam melangsungkan perkawinan dan membentuk keluarga.

Menggunakan penafsiran gramatikal, maka Pasal 2 ayat (1) UU No. 1 Tahun 1974, bermakna bahwa perkawinan adalah sah jika ketentuan yang ada dalam masing-masing agama (hukum agama) dan kepercayaannya telah terpenuhi.

\section{Fungsi pencatatan pada Kantor Catatan} Sipil

Pasal 2 ayat (2) Undang-undang Nomor 1/1974 menyatakan bahwa tiap-tiap perkawinan dicatat menurut peraturan perundang-undangan yang berlaku. Pasal 2 ini bermakna bahwa setelah melangsungkan perkawinan menurut agama masing-masing, perkawinan tersebut wajib dicatatkan.

Peraturan Pemerintah Nomor 9 Tahun 1975 tentang Pelaksanaan Undang-undang Nomor 1 Tahun 1974 tentang Perkawinan (PP No. 9/1975) menjelaskan suatu perkawinan dapat dicatatkan dengan ketentuan sebagai berikut:

1) Warga Negara yang hendak melangsungkan perkawinan memberitahukan kepada pegawai pencatat perkawinan di tempat perkawinan akan dilangsungkan (Pasal 3 ayat (1) PP. No. 9/1975).

2) Pegawai pencatat perkawinan melakukan pemeriksaan mengenai pemenuhan syarat dan halangan perkawinan (Pasal 6 ayat (1) PP. No. 9/1975).

3) Pegawai pencatat perkawinan mengumumkan rencana perkawinan apabila syarat perkawinan telah terpenuhi (Pasal 8 PP. No. 9/1975).

4) Perkawinan dilaksanakan menurut tata cara hukum masing-masing agama dan kepercayaan (Pasal 10 ayat (2) PP. No. 9/1975). 
5) Pencatatan perkawinan (Pasal 11 PP. No. 9/1975).

Hambatan yang terkadang dialami oleh pasangan perkawinan campuran adalah pegawai pencatat perkawinan (dalam hal ini Kantor Catatan Sipil) menolak untuk mencatatkan perkawinan campuran tersebut dengan alasan adanya perbedaan agama antara pasangan tersebut. Hal ini mengakibatkan jaminan hukum oleh Negara terkait hak-hak pasangan tidak dapat terpenuhi dengan baik, karena perkawinan campuran dianggap tidak ada karena tidak tercatat.

Undang-undang Nomor 24 Tahun 2013 tentang Administrasi Kependudukan ( UU No. 24/2013) menyatakan bahwa perkawinan yang sah berdasarkan ketentuan peraturan perundang-undangan wajib dicatatkan paling lambat 60 hari sejak tanggal perkawinan (Pasal 34 ayat (1)). Seharusnya pasangan perkawinan campuran yang telah melangsungkan perkawinan sah berdasarkan hukum agama, dapat mencatatkan perkawinannya tanpa ada permasalahan.

Maria Farida Indrati dalam concurring opinion Putusan Mahkamah Konstitusi Nomo 46/PUU-VIII/2010 menyatakan bahwa ketika perkawinan dilangsungkan tanpa mengikuti hukum agama dan kepercayaan sehingga perkawinannya dianggap tidak sah, maka perkawinan menjadi tidak bisa dicatatkan karena perkawinannya dianggap tidak pernah terjadi. Akibat dari tidak adanya pencatatan pasangan adalah tidak ada perlindungan yang diberikan kepada pasangan yang melangsungkan perkawinan beda agama dan kepercayaan.

UU No. 24/2013 Pasal 35 huruf a menyebutkan bahwa pencatatan perkawinan berlaku juga bagi perkawinan yang ditetapkan oleh Pengadilan. Penjelasan Pasal 35 huruf a menjelaskan yang dimaksud ditetapkan oleh Pengadilan adalah perkawinan yang dilakukan oleh antar umat yang berbeda agama.

Kesimpulan Pasal 34 dan Pasal 35 huruf a adalah pencatatan perkawinan merupakan suatu kewajiban yang dilakukan oleh pasangan yang telah menikah baik antara yang memiliki agama sama maupun bagi yang berbeda agama. Bagi pasangan yang berbeda agama, maka pencatatan perkawinan dilakukan tidak hanya berdasarkan sahnya perkawinan menurut hukum agama namun juga berdasarkan putusan pengadilan.

Pemerintah dalam pembelaannya dalam perkara uji materiil No. 68/PUU-XII/2014 menegaskan bahwa sah atau tidaknya sebuah perkawinan ditentukan oleh masing-masing agama yang diakui di Indonesia bukan oleh Negara. Sepanjang agama-agama yang diakui di Indonesia menyatakan bahwa sebuah perkawinan adalah sah, maka Negara hanya 
mencatatkan saja perkawinan tersebut ke sistem administrasi Negara. ${ }^{9}$

Pemerintah juga menyebutkan bahwa penulisan Pasal 2 UU No. 1/1974 telah memenuhi unsur Ketuhanan dan unsur administratif serta menunjukkan adanya pemisahan pengaturan (separation of rules). Pasal 2 ayat (1) UU No. 1/1974 menegaskan unsur Ketuhanan dengan membebaskan tiap agama untuk mengatur sahnya perkawinan, sedangkan Pasal 2 ayat (2) UU No. 1/1974 menegaskan Negara mengatur secara absolut untuk mendaftarkan perkawinannya secara administratif.

Mahkamah Agung juga mengeluarkan surat Ketua MA RI Nomor KMA/72/4/1981 tentang Perkawinan Campuran kepada Menteri Agama dan Menteri Dalam Negeri yang pada intinya menyatakan karena Pasal 2 ayat (1) UU No. 1/1974 tidak mengatur perkawinan antaragama secara eksplisit maka terjadi kekosongan hukum. Mahkamah Agung juga melalui putusan Nomor 1400K/PDT/11986 memerintahkan Kantor Catatan Sipil untuk memasukkan dan mencatat perkawinan campuran antara Andy Voni Gani dengan Andrianus Petrus Hendrik.

Mengenai peran Negara dalam perkawinan juga dapat dilihat dari putusan MK No. 46/PUU-VIII/2010 yang menetapkan bahwa pencatatan perkawinan bukanlah merupakan faktor yang menentukan sahnya perkawinan dan pencatatan perkawinan merupakan kewajiban administratif.

Pertimbangan Mahkamah Konstitusi dalam Putusan MK 68/PUU-XII/2014 menyebutkan bahwa agama menetapkan tentang keabsahan perkawinan, sedangkan Undang-Undang menetapkan keabsahan administratif yang dilakukan oleh Negara.

Mahkamah Konstitusi dalam putusan MK No. 46/PUU-VII/2010 berpendapat makna kewajiban administratif sebagai berikut:

1. Pencatatan dimaksud diwajibkan dalam rangka fungsi negara memberikan jaminan perlindungan, pemajuan, penegakan, dan pemenuhan hak asasi manusia yang bersangkutan yang merupakan tanggung jawab negara dan harus dilakukan sesuai dengan prinsip negara hukum yang demokratis yang diatur serta dituangkan dalam peraturan perundang-undangan [vide Pasal 28I ayat (4) dan ayat (5) UUD 1945].

2. Pencatatan secara administratif yang dilakukan oleh negara dimaksudkan agar perkawinan, sebagai perbuatan hukum penting dalam kehidupan yang dilakukan oleh yang bersangkutan, yang berimplikasi terjadinya akibat hukum yang sangat luas, di kemudian hari dapat dibuktikan dengan bukti yang sempurna dengan suatu akta

\footnotetext{
${ }^{9}$ Putusan Mahkamah Konstitusi Nomor 68/PUU-XII/2014 terkait uji materiil terhadap Pasal 2 ayat (1) UU. No. 1/1974, hlm. 91.
} 
otentik, sehingga perlindungan dan menurut agama Kristen, Katolik, Budha, pelayanan oleh Negara terkait dengan hak- Hindu, dan Konghucu.

hak yang timbul dari suatu perkawinan

a. Kristen

yang bersangkutan dapat terselenggara

Kristen Protestan memandang secara efektif dan efisien. Artinya, dengan dimilikinya bukti otentik perkawinan, hakhak yang timbul sebagai akibat perkawinan dapat terlindungi dan terlayani dengan baik, karena tidak diperlukan proses pembuktian yang memakan waktu, uang, tenaga, dan pikiran yang lebih banyak, seperti pembuktian mengenai asal-usul anak dalam Pasal 55 UU 1/1974 yang mengatur bahwa bila asal-usul anak tidak dapat dibuktikan dengan akta otentik maka mengenai hal itu akan ditetapkan dengan putusan pengadilan yang berwenang. Pembuktian yang demikian pasti tidak lebih efektif dan efisien bila dibandingkan dengan adanya akta otentik sebagai buktinya;

\section{Hukum agama}

Penjelasan diperbolehkannya dan sahnya perkawinan agama menurut hukum agama masing-masing, penulis akan menggunakan keterangan ahli dan ulasan yang digunakan dalam permohonan perkara MK No. 68/PUUXII/2014, namun karena penelitian ini fokus pada perkawinan beda agama antara sesama non-muslim, maka untuk perkawinan menurut agama Islam, tidak dicantumkan dalam penelitian ini. Berikut adalah penjelasan terkait perkawinan beda agama perkawinan beda agama sebagai berikut:

i. Dilarang

Pandangan ini didasarkan pada Injil Korintus 6:14-18. Apabila perkawinan beda agama terjadi, gereja dapat mengeluarkan anggotanya yang melangsungkan perkawinan beda agama tersebut dari gereja.

ii. Diperbolehkan dengan menyediakan langkah-langkah yang dapat ditempuh bagi perkawinan beda agama dan kepercayaan.

Pendapat ini didasari pada pandangan yang menyatakan bahwa agama Kristen Protestan tidak menghalangi kalau terjadi perkawinan beda agama dan kepercayaan antara penganut Protestan dengan agama atau kepercayaan lain dan memberikan langkah-langkah yang dapat diambil, berupa:

a) mereka dianjurkan untuk melangsungkan perkawinan secara sipil dimana kedua pihak tetap menganut agama masing-masing; dan

b) kepada mereka diadakan penggembalaan khusus; 
b. Katolik

Gereja memberi adanya kemungkinan adanya perkawinan beda agama dan kepercayaan, yang menurut Kanon 1086 adalah perkawinan antara 1 (satu) orang yang telah dibaptis dalam Gereja Katolik dan yang tidak dibaptis (orang yang beragama selain Katolik/Kristen termasuk aliran kepercayaan). Perkawinan beda agama dan kepercayaan ini pada dasarnya dilarang, namun sesuai Kanon 1086 dimungkinkan adanya dispensasi apabila dapat memenuhi syarat-syarat dalam Kanon 1125, yaitu:

1) pihak Katolik menyatakan bersedia menjauhkan bahaya meninggalkan iman serta memberikan janji jujur bahwa ia akan berbuat segala sesuatu dengan sekuat tenaga, agar semua anaknya dibaptis dan dididik dalam Gereja Katolik;

2) mengenai janji-janji yang harus dibuat oleh pihak Katolik itu, pihak yang lain hendaknya diberitahu pada waktunya, sedemikian sehingga jelas bahwa ia sungguh sadar akan janji dan kewajiban pihak Katolik; dan

3) kedua pihak hendaknya diajar mengenai tujuan-tujuan dan ciri-ciri hakiki perkawinan, yang tidak boleh dikecualikan oleh seorangpun dari keduanya. c. Budha

Menurut Sangha Agung Indonesia sebagaimana dikutip oleh Q.S. Eoh perkawinan beda agama dan kepercayaan diperbolehkan, seperti yang melibatkan penganut agama Buddha dan penganut non-Buddha. Asal pengesahannya dilakukan menurut tata cara agama Buddha. Calon mempelai yang bukan Buddha tidak diharuskan untuk masuk Buddha terlebih dahulu. Akan tetapi, dalam upacara ritual perkawinan, kedua mempelai diwajibkan mengucapkan "atas nama Sang Buddha", "Dharma dan Sangka", yang merupakan dewa-dewa umat Buddha.

Dalam pandangan Bhiksu Prajnavitra Mahasthavira, sesuai dengan ajaran Buddha yang universal. Perkawinan adalah sebuah dharma. Hal yang paling diutamakan adalah perkawinan tidak lepas dari ajaran moral. Dengan demikian pemberkatan untuk kedua mempelai dilakukan. Karena pemberkatan sangat diperlukan, maka yang diutamakan adalah agama kedua mempelai yang sama. Namun demikian, banyak terjadi kasus perkawinan beda agama dan kepercayaan yang melibatkan penganut agama Buddha. Bhiksu Prajnavira melihat hal ini sebagai sesuatu yang fleksibel, asal tidak melanggar dharma, dan tidak menyimpang dari norma moral. "Jadi tidak tertutup rapat ketika masing-masing keluarga sudah 
saling sepakat dan menyetujui." Posisi Biku atau Bhiksu hanyalah memberkati. Sementara yang meresmikan perkawinan tersebut adalah keluarga masing- masing yang diwakilkan kepada seorang Dharmaduta, yakni orang yang diangkat oleh Biku atau Bhiksu untuk meresmikan perkawinan.

d. Hindu

Menurut hukum agama Hindu, perkawinan itu sah apabila dilakukan di hadapan pendeta. Bila ada salah satunya bukan beragama Hindu, maka ia diwajibkan menjadi penganut agama Hindu. Sebelum hari perkawinan harus dibuatkan upacara sudhiwadani yang mengandung pengertian menyucikan ucapan atau mengubah tatanan, baik dari sudut perilaku, ucapan, dan pikiran tentang keyakinan serta kepercayaan ke hadapan Tuhan, harus sesuai dengan tatanan pelaksanaan agama Hindu.

Adapun persyaratan untuk melakukan upacara suhdiwadhani, yaitu:

1) Pernyataan diri dari salah satu mempelai akan mengalihkan agama menjadi agama Hindu, kecuali umurnya di bawah 25 (dua puluh lima) tahun, diperlukan surat pernyataan persetujuan dari orang tuanya bahwa akan mengalihkan agama menjadi agama Hindu; dan
2) Surat keterangan dari penjuru Banjar (Kelihan Adat) atau mengusulkan kepada Parisada Hindu Dharma Indonesia atau Bimas Hindu setempat untuk diminta pengesahannya berupa piagam.

Berdasarkan uraian di atas, dapat disimpulkan bahwa agama Hindu tidak mengena ladanya perkawinan antar agama (beda agama) karena terhadap pasangan yang salah satunya tidak beragama Hindu harus terlebih dahulu dilakukan upacara keagamaan mengalihkan agamanya menjadi Hindu.

e. Konghucu

Dalam aliran kepercayaan Konghucu tidak terdapat aturan khusus yang membolehkan atau melarang perkawinan 2 (dua) insan yang berbeda keyakinan. Sebuah perkawinan dinyatakan sah apabila terjadi antara laki- laki dan perempuan dewasa, tidak ada unsur paksaan, disetujui atau atas kemauan kedua belah pihak, mendapat restu kedua orang tua atau yang dituakan, diteguhkan dalam sebuah upacara keagamaan, meski untuk salah satu tidak diharuskan berpindah keyakinan terlebih dahulu. Pandangan tokoh dan ahli aliran kepercayaan Konghucu juga tidak melarang adanya perkawinan antara 2 (dua) insan yang berbeda keyakinan.

Berdasarkan penjelasan di atas maka dapat disimpulkan bahwa sahnya suatu 
perkawinan bukan ditentukan oleh pencatatan yang dilakukan di Kantor Catatan Sipil atau Negara namun didasarkan atas hukum agama. Putusan Mahkamah Konstitusi dan pendapat berbeda Dr. Maria Farida Indrati tidak menyebutkan dan tidak memberikan larangan yang tegas terhadap pelaksanaan perkawinan campuran di Indonesia. Sehingga walaupun telah ada putusan Mahkamah Konstitusi tersebut yang pada intinya menolak permohonan pemohon dan menyatakan Pasal 2 ayat (1) tetap seperti semula, maka ke depan perkawinan campuran masih dapat terjadi atau dilakukan oleh para pihak sepanjang hukum agamanya memungkinkan dan mensahkan perkawinan tersebut.

Hak Waris Anak Hasil Perkawinan Campuran

Permasalahan terkait perkawinan campuran tidak hanya sekedar tentang sahnya suatu perkawinan atau dicatatkannya perkawinan tersebut di Kantor Catatan Sipil, namun juga terkait hak mewaris dari anak yang lahir dalam masa perkawinan tersebut. Keabsahan perkawinan menentukan apakah anak tersebut merupakan anak sah atau anak luar kawin yang berdampak kepada warisan yang diterimanya.
Sebagaimana telah dijelaskan bahwa sahnya perkawinan ditentukan oleh hukum agama bukan oleh Negara, namun Negara memiliki kewenangan absolut dalam hal pencatatan. Apabila perkawinan campuran dilakukan dan dicatatkan akan memiliki dampak yang berbeda dengan perkawinan campuran yang tidak dicatatkan ( karena ditolak Kantor Catatan Sipil). Umumnya apabila terjadi permasalahan hukum, penegak hukum biasanya akan selalu menanyakan akta perkawinan yang dikeluarkan sebagai alat bukti bahwa telah terjadi perkawinan. Apabila tidak dapat menunjukkan akta perkawinan, maka perkawinan tersebut dianggap sebagai "kumpul kebo". 10

Berkaca dari putusan MK No. 68/PUUXII/2014, bahwa sahnya perkawinan ditetapkan menurut hukum agama, maka seharusnya pencatatan perkawinan tidak berdampak terhadap ada atau tidaknya suatu perkawinan namun mengenai tertib administrasi, yaitu Negara memiliki daftar pasangan yang melakukan perkawinan di Indonesia. Namun demikian walaupun sahnya ditentukan oleh hukum agama, UU Administrasi Kependudukan telah menyebutkan bahwa perkawinan campuran wajib didaftarkan dengan Penetapan Pengadilan. Artinya, setelah melakukan perkawinan, maka pasangan tersebut masih

10 Putusan Mahkamah Konstitusi Nomor 68/PUU-XII/2014 terkait uji materiil terhadap Pasal 2 ayat (1) UU. No. 1/1974, hlm. 67. 
harus mengajukan permohonan penetapan pengadilan untuk dicatatkan. Namun, konsekuensi dari penetapan pengadilan adalah, permohonan tersebut dapat ditolak atau diterima. Apabila diterima, perkawinan campuran akan dicatatkan dalam Kantor Catatan Sipil dan memenuhi persyaratan sebagaimana Pasal 2 UU No. 1/1974. Sedangkan jika tidak diterima permohonannya, maka tidak dapat dicatatkan di Kantor Catatan Sipil dan artinya tidak memenuhi Pasal 2 UU No. 1/1974 dan jika berkaca dari penetapan pengadilan yang sudah terjadi, apabila ditolak pengadilan maka perkawinan tersebut dianggap tidak ada oleh Negara.

Peneliti dalam penelitian ini akan membahas hak waris ahli waris baik bagi perkawinan campuran yang dicatatkan maupun tidak dicatatkan. Adapun alasan penulis membahas keduanya karena baik dicatatkan maupun tidak dicatatkan, apabila hukum agama telah menentukan perkawinan sah maka sejatinya perkawinan tersebut sah berdasarkan hukum agama.

Penjelasan umum angka 4 huruf $\mathrm{b}$ UU No. 1/1974 tentang asas-asas atau prinsipprinsip perkawinan menyatakan:

“...bahwa suatu perkawinan
adalah sah bilamana
dilakukan menurut hukum
masing-masing agamanya
dan kepercayaannya itu; dan
di samping itu tiap-tiap
perkawinan harus dicatat
menurut peraturan

perundang-undangan yang berlaku. Pencatatan tiap-tiap perkawinan adalah sama halnya dengan pencatatan peristiwa-peristiwa penting dalam kehidupan seseorang, misalnya kelahiran, kematian yang dinyatakan dalam kehidupan seseorang, misalnya kelahiran, kematian yang dinyatakan dalam suratsurat keterangan, suatu akte yang juga dimuat dalam daftar pencatatan".

Berdasarkan penjelasan tersebut nyata bahwa pencatatan perkawinan bukan faktor yang menentukan sahnya perkawinan dan pencatatan merupakan kewajiban administratif yang diwajibkan berdasarkan peraturan perundang-undangan semata-mata memudahkan untuk proses pembuktian adanya perkawinan karena akta perkawinan merupakan akta otentik.

Pengaturan mengenai hak sebagai ahli waris dapat dilihat dari beberapa peraturan yang ada di Indonesia, yaitu:

\section{KUHPerdata}

Kitab Undang-undang Hukum Perdata telah menentukan syarat sebagai ahli waris adalah adanya hubungan darah baik sah maupun luar kawin (Pasal 832 KUHPerdata). Pasal 832 KUHP menentukan bahwa hubungan darah menjadi penentu utama apakah anak berhak menjadi ahli waris atau tidak. Status perkawinan dalam hal ini tidak menjadi persoalan karena perkawinan sah 
atau tidak, tidak mempengaruhi hak mewaris anak.

Berdasarkan ketentuan Pasal 832 KUHPerdata, sudah jelas bahwa secara hukum,baik perkawinan tersebut tercatat atau tidak tercatat selama ada hubungan antara anak dengan orang tua, maka anak tetap menjadi ahli waris.

\section{UU No. 1/1974 tentang Perkawinan}

Kedudukan anak dalam UU No. 1/1974 diatur dalam Pasal 42 dan Pasal 43 yang masing-masing berbunyi:

a) Pasal 42:

Anak yang sah adalah anak yang dilahirkan dalam atau sebagai akibat perkawinan yang sah.

b) Pasal 43 ayat (1):

Anak yang dilahirkan di luar perkawinan hanya mempunyai hubungan perdata dengan ibunya dan keluarga ibunya.

Melihat ketentuan di atas dihubungkan dengan perkawinan yang sah, maka seharusnya bagi perkawinan yang sah, anak memiliki hak waris seutuhnya. Bagi perkawinan campuran yang telah sah secara agama dan dicatatkan maka bagi pihak suami, istri dan anak semuanya mendapatkan perlindungan dari Negara sebagaimana telah disebutkan bahwa pencatatan merupakan syarat administratif yang menimbulkan tugas Negara dalam melindungi pihak-pihak yang ada dalam sebuah lembaga perkawinan termasuk anak. Sehingga dalam hal ini, anak memiliki hak waris.
Namun demikian, tampaknya hal ini hanya berlaku bagi pasangan yang telah mencatatkan perkawinannya walaupun sebenarnya perkawinan tersebut telah sah secara agama. Hal ini dapat dilihat dalam uji materiil yang diajukan oleh $H$. Aisyah Mochtar dalam perkawinan yang dilangsungkannya dengan Drs. Moerdiono, dimana perkawinan tersebut telah sah secara agama dan telah memperoleh penetapan pengadilan Nomor 46/Pdt.P/2008/PA.Tgrs. Permasalahan muncul ketika pada saat perceraiaran, H. Aisyah Mochtar menuntut harta gono gini namun ditolak oleh Drs Moerdiono karena menganggap perkawinan yang telah dilakukan tidak sah karena tidak tercatat.

Walaupun dalam hal ini, antara $\mathrm{H}$. Asiyah dan Drs. Moerdiono beragama Islam, namun penulis menggunakan putusan tersebut dengan alasan bahwa perkawinan tersebut tidak tercatat. Hal yang sama juga dapat terjadi pada perkawinan campuran yang tidak dicatatkan atau ditolak oleh pengadilan sehingga hasilnya adalah tidak adanya akta perkawinan yang dikeluarkan oleh Kantor Catatan Sipil.

H. Aisyah Mochtar pun dalam uji materiilnya juga mengungkapkan bahwa dirinya dirugikan dengan adanya Pasal 2 UU No. 1/1974 karena dengan adanya pasal ini, perkawinan yang telah dilakukan seakan-akan tidak sah di hadapan Negara. Mahkamah Konstitusi dalam hal ini berpendapat lain dan 
menolak dalil pemohon karena sahnya perkawinan bukan karena pencatatan namun karena hukum agama masing-masing. Sehingga jika, agama telah mensahkan perkawinan maka perkawinan itu sah.

H. Aisyah Mochtar juga mengajukan uji materiil Pasal 43 dimana pemohon dirugikan dengan adanya kata "di luar perkawinan" sehingga seakan-akan perkawinannya tidak sah sehingga anak tidak dapat memiliki hubungan keperdataan (salah satunya hak waris) dengan ayah.

Demikian dengan permohonan tersebut, Mahkamah Konstitusi mengajukan pendapat dan memberikan penafsiran terhadap Pasal 43 dengan pertimbangan bahwa Akibat hukum dari peristiwa hukum kelahiran karena kehamilan, yang didahului dengan hubungan seksual antara seorang perempuan dengan seorang laki-laki, adalah hubungan hukum yang di dalamnya terdapat hak dan kewajiban secara bertimbal balik, yang subjek hukumnya meliputi anak, ibu, dan bapak.

Berdasarkan uraian di atas, hubungan anak dengan seorang laki-laki sebagai bapak tidak semata-mata karena adanya ikatan perkawinan, akan tetapi dapat juga didasarkan pada pembuktian adanya hubungan darah antara anak dengan laki-laki tersebut sebagai bapak. Dengan demikian, terlepas dari soal prosedur/administrasi perkawinannya, anak yang dilahirkan harus mendapatkan perlindungan hukum. Jika tidak demikian, maka yang dirugikan adalah anak yang dilahirkan di luar perkawinan, padahal anak tersebut tidak berdosa karena kelahirannya di luar kehendaknya. Anak yang dilahirkan tanpa memiliki kejelasan status ayah seringkali mendapatkan perlakuan yang tidak adil dan stigma di tengah-tengah masyarakat. Hukum harus memberi perlindungan dan kepastian hukum yang adil terhadap status seorang anak yang dilahirkan dan hak-hak yang ada padanya, termasuk terhadap anak yang dilahirkan meskipun keabsahan perkawinannya masih dipersengketakan; ${ }^{11}$

Mahkamah Konstitusi pada akhirnya memberikan putusan bahwa berdasarkan uraian tersebut di atas maka Pasal 43 ayat (1) UU 1/1974 yang menyatakan, "Anak yang dilahirkan di luar perkawinan hanya mempunyai hubungan perdata dengan ibunya dan keluarga ibunya" harus dibaca, "Anak yang dilahirkan di luar perkawinan mempunyai hubungan perdata dengan ibunya dan keluarga ibunya serta dengan laki-laki sebagai ayahnya yang dapat dibuktikan berdasarkan ilmu pengetahuan dan teknologi dan/atau alat bukti lain menurut hukum mempunyai hubungan darah, termasuk hubungan perdata dengan keluarga ayahnya"; ${ }^{12}$

\footnotetext{
${ }^{11}$ Putusan Mahkamah Konstitusi Nomor 46/PUU-VIII/2010, hlm. 35.

12 Putusan Mahkamah Konstitusi Nomor 46/PUU-VIII/2010, hlm. 39.
} 
Kedudukan hukum hak mewaris anak dalam perkawinan campuran antara sesama Non-muslim (perkawinan campuran yang sah secara agama) namun tidak tercatat di Kantor Catatan Sipil perlu mendapatkan kejelasan. Anak sebagai hasil hubungan antara suami dan istri perlu mendapatkan perlindungan hukum khususnya dalam penelitian ini perlindungan hukum mengenai hak mewaris anak.

Putusan Mahkamah Konstitusi merupakan salah satu bentuk perlindungan hukum yang diberikan kepada para pihak. Putusan Mahkamah Konstitusi, sesuai dengan kewenangan Mahkamah Konstitusi, maka berlaku secara mengikat tidak hanya kepada para pihak yang mengajukan gugatan namun juga berlaku bagi siapa pun setelah keluarnya putusan tersebut.

Setiap orang wajib menafsirkan sesuai dengan putusan Mahkamah Konstitusi termasuk mengenai Pasal 43 ayat (1) UU 1/1974 yang berlaku bagi hak mewaris anak dalam perkawinan campuran antara sesama Non-Muslim yang tidak tercatat. Hukum agama masing-masing suami atau istri (apabila ada yang mengatur mengenai hak mewaris anak) tidak berlaku karena bukan hukum positif dan digunakan Putusan Mahkamah Konstitusi.

Perkawinan campuran antara sesama Non-Muslim yang telah tercatat, anak tetap memiliki hak mewaris tanpa perlu diberlakukannya putusan Mahkamah Konstitusi.

Putusan Mahkamah Konstitusi yang memberikan pengertian baru terhadap Pasal 43 ayat (1) UU 1/1974, maka setiap anak hasil hubungan antara suami istri dan dapat dibuktikan adanya hubungan darah tetap memiliki hak waris walaupun perkawinannya tidak dicatat. Artinya, apabila ada perkawinan campuran dan tidak tercatat maka, anak yang memiliki hubungan dengan dengan pihak ibu dan bapak tetap dapat memiliki hak waris.

\section{KESIMPULAN}

Putusan Mahkamah Konstitusi Nomor 68/PUU-XI/2014 tidak memberikan larangan yang tegas apakah perkawinan campuran dapat dilakukan di Indonesia sehingga perkawinan campuran masih memungkinkan untuk dilakukan sepanjang hukum agama memperbolehkan hal tersebut.

Anak yang memiliki hubungan darah dengan bapak dan ibu tetap memiliki hubungan keperdataan termasuk hak waris sepanjang dapat dibuktikan adanya hubungan darah terlepas dari permasalahan pendaftaran perkawinan.

\section{DAFTAR PUSTAKA}

\section{Buku}

Ahmad Nuryani, 2010, Dasar Hukum

Pencatatan Pernikahan di Indonesia, Kantor Urusan Agama Kecamatan Gedebage, Bandung. 
Indriaswari Dyah Saptaningrum, 2000, Sejarah UU No: 1 tahun 1974 tentang Perkawinan dan Pembakuan Peran Gender, dalam Perspektif Perempuan, Lembaga Bantuan Hukum Asosiasi Perempuan Untuk Keadilan, Jakarta.

Johny Ibrahim, 2007, Teori \& Metodologi Penelitian Hukum Normatif, Bayumedia Publishing, Malang.

Martiman Prodjohamidjojo, 2008, Hukum Perkawinan Indonesia, Indonesia Legal Center Publishing, Jakarta.

M. Indra Ridwan, 1994, Hukum Perkawinan di Indonesia Cetakan 1, , CV. Haji Masangung, Jakarta.

Nani Suwondo, 1992, Kedudukan Wanita Indonesia Dalam Hukum dan Masyarakat, Ghalia Indonesia, Jakarta.

R. Soetojo Prawirohamidjojo, 1994, Pluralisme Dalam Perundangundangan Perkawinan Indonesia, Airlangga University Press, Surabaya.

Siska Lis Sulistiai, 2015, Kedudukan Hukum Anak, Refika Aditama, Bandung.

Soebekti dan Tjitrosudibio, 2008, Hukum Waris Tanpa Wasiat, Badan Penerbit Universitas Diponegoro Semarang, Semarang.

Soerjono Soekanto dan Sri Mamudji, 2004, Penelitian Hukum Normatif, PT. Raja Grafindo Persada, Jakarta.

\section{Jurnal}

Dio Permana Putra, Makna Pasal 2 UndangUndang Nomor 1 Tahun 1974 Tentang Perkawinan Terkait Syarat Sah Perkawinan Ditinjau Dari Perspektif Sejarah Dan Putusan Mahkamah Konstitusi, Skripsi Fakultas Hukum Universitas Brawijaya, 2015.

\section{Peraturan Perundang-Undangan}

Undang undang Dasar Negara Republik Indonesia 1945

Undang undang Nomor 1 Tahun 1974 tentang Perkawinan

Kitab Undang-undang Hukum Perdata

\section{Putusan Pengadilan}

Putusan Mahkamah Konstitusi Nomor 68/PUU-XII/2014.

Putusan Mahkamah Konstitusi Nomor 46/PUU-VII/2010

Putusan Mahkamah Agung Nomor 156 /Pdt. P/2010/PN.Ska

Putusan Mahkamah Agung Nomer 112/Pdt. P/2 008 /PN.Ska

\section{Naskah Internet}

http://nasional.kompas.com/read/2014/09/06/ 09352001/UU.Perkawinan.Mendiskrim inasi.Pasangan.Beda.Agama,

http://www.hukumonline.com/klinik/detail/cl 290/gimana-caranya,

http://www.hukumonline.com/berita/baca/ho 16268/uu-perkawinan-tidak-melarangperkawinan-beda-agama,

http://www.hukumonline.com/berita/baca/lt5 423d8219fb45/ini-pandangan-pendetahkbp-seputar-nikah-beda-agama,

http://www.stmaria.info/read/beritarohani/mixed-marriage-withsomebody-not-the-same-religionperkawinan-beda-agama-menurutgereja-katolik\#.Wb81iYglHIU 